\title{
PEMBENTUKAN CITRA NEGATIF CALON PRESIDEN JOKO WIDODO JELANG PEMILIHAN PRESIDEN 2019
}

\section{THE BUILD OF A PRESIDENTIAL CANDIDATE JOKO WIDODO'S NEGATIVE IMAGE ON THE APPROACHING 2019 PRESIDENTIAL ELECTION}

\author{
Ali Kusno \\ Kantor Bahasa Kalimantan Timur \\ Jalan Batu Cermin 25, Sempaja Utara, Samarinda, Kalimantan Timur \\ Pos-el: ali.kusno@kemdikbud.go.id
}

*) Naskah diterima: 26 September 2019; direvisi: 15 November 2019; disetujui: 3 Desember 2019

\begin{abstract}
Abstrak
Penelitian tersebut merupakan penelitian pembentukan citra negatif pasangan calon presiden Jokowi-Ma'ruf Amin. Penelitian ini menggunakan metode penelitian kualitatif yang bersifat deskriptif. Data dan sumber data yang digunakan dalam penelitian ini berupa dokumen. Beragam persepsi negatif yang disematkan kepada Jokowi. Berbagai serangan negatif tersebut sebagai bentuk perlawanan atas berbagai prediksi yang menyatakan bahwa pasangan calon presiden petahana Jokowi dan Ma'ruf Amin akan menjadi pemenang Pilpres 2019 mengalahkan pasangan Prabowo dan Sandiaga Uno. Berbagai isu negatif disebarkan untuk menurunkan elektabilitas Jokowi-Ma'ruf. Isu yang menyerang Jokowi pada Pilpres 2014 dan 2019 adalah Jokowi seorang PKI dan pembangunan infrastruktur yang hanya untuk kalangan berada. Jokowi mendapat serangan bahwa pro terhadap asing dan aseng. Pada masa kampanye Pilpres 2019, Jokowi banyak diserang dengan isu LGBT dan harga pangan yang naik. Apabila dicermati, penggunaan berbagai isu negatif tersebut terbukti mampu menggerus peta suara pasangan Jokowi-Ma'ruf. Hanya saja penggunaan berbagai isu negatif untuk menyerang pihak lain sangat berbahaya dan terbukti memecah belah masyarakat.
\end{abstract}

Kata kunci: citra negatif, pilpres, Jokowi

\begin{abstract}
The research was a research about the building of a negative image of presidential and vice presidential candidates, Jokowi-Ma'ruf Amin. About the building of a negative image of presidential and vice presidential candidates, Jokowi-Ma'ruf Amin uses descriptive qualitative research methods. Data and data sources used in this study are documents. Various negative images were pinned to Jokowi. These negative images are a form of resistance against various predictions stating that the incumbent presidential candidate and vice presidential candidate, Jokowi and Ma'ruf Amin, will be the winners of the 2019 presidential election defeating Prabowo and Sandiaga Uno. Various negative issues were spread to reduce the electability of Jokowi-Ma'ruf. The issues that bombarded Jokowi in 2014 and 2019 presidential Jokowi was accused of being too soft on foreigners and 'aseng'. During the 2019 presidential election campaign, Jokowi was also attacked with the issues of LGBT and the rise of food prices. The use of various negative issues has proven to erode Jokowi-Ma'ruf's electoral map. The imposition of various negative issues to attack other parties is very dangerous and is proven to disrupt the community.
\end{abstract}

Keywords: negative image, presidential election, Jokowi 


\section{PENDAHULUAN}

Gelaran Pemilihan Presiden 2019 sudah selesai dengan ditetapkannya calon presiden Joko Widodo dan Ma'ruf Amin sebagai pemenang dengan mengalahkan pasangan capres Prabowo Sandiaga Uno. Kontestasi pemilihan presiden pada tahun 2019 cukup memicu adanya pertentangan di masyarakat. Masyarakat Indonesia seolah terpecah menjadi dua kubu.

Isu SARA berkembang di masyarakat. Besarnya pertentangan dalam Pemilu 2019 merupakan akumulasi pertarungan politik kedua kubu sejak Pemilihan Umum 2014, antara pasangan Jokowi dan Jusuf Kalla dengan Prabowo dan Hatta Rajasa. Dalam Pemilu tersebut dimenangkan pasangan Jokowi Kalla.

Kontestasi politik sebelum Pemilihan Presiden sudah memanas sejak Pemilihan Gubernur DKI Jakarta, antara pasangan Anis Sandi dan Ahok Djarot. Gaya politik dalam Pilkada DKI Jakarta dengan banyak menggunakan isu SARA cukup membelah publik. Sisa-sisa panasnya politik Pilkada DKI Jakarta terbawa ke dalam Pilpres 2019.

Pada masa kampanye, berbagai isu negatif saling menyerang antara capres satu dengan lainnya. Salah satu pasangan capres yang paling banyak diterpa serangan kampanye negatif, dilakukan terhadap capres Joko Widodo.

Berdasarkan penelitian berbagai lembaga survei tentang terpaan isu negatif membuat elektabilitas suara capres Jokowi Ma'ruf turun. Dalam perkembangannya, perolehan suara pasangan Jokowi-Ma'ruf dengan Prabowo-Sandi selisihnya tidak lebih dari lima persen. Hal itu sedikit banyak dipengaruhi oleh berbagai isu negatif yang dialamatkan terhadap capres Jokowi.

Direktur Eksekutif Para Syndcate Arie Nurcahyo menyebut tren elektabilitas pasangan Joko Widodo-Ma'ruf Amin meng- alami penurunan. Sementara tren pasangan Prabowo Subianto-Sandiaga Uno cenderung naik.

Awalnya, Arie menjelaskan kesimpulan tren elektabilitas ini diambil melalui beberapa lembaga survei yang dirilis sejak penetapan nama cawapres, yaitu pada Agustus hingga November 2019. Pasangan JokowiMa'ruf trennya menurun karena beberapa faktor. Tren keduanya dari beberapa lembaga survei cenderung elektabilitas capres stagnan, tetapi kalau dikumpulkan semua hasil survei dan ditarik regenerasi linier tren gradien, untuk Jokowi-Ma'ruf gradiennya negatif itu minus. Secara umum, pergerakan Jokowi-Ma'ruf trennya menurun sedangkan untuk Prabowo-Sandi itu trennya justru naik walaupun tipis.

Ada fenomena naiknya jumlah pemilih yang belum menentukan pilihan (undecided votters). Fenomena ini menarik untuk dicari penyebabnya. Setelah ditarik garis lurus dari beberapa survei terbaca, undecided votters itu naik, ini menarik apakah ini yang memilih Jokowi ragu atau separuh suaranya memilih Prabowo-Sandi atau yang lainnya. Arie kemudian merinci faktor yang membuat Jokowi-Ma'ruf menurun. Salah satunya adalah karena strategi pemenangan Jokowi-Ma'ruf dinilai monoton dan terkadang terhanyut dengan permainan politik lawan yang cenderung memainkan wacana retorika.

Pertama, strategi pemenangan JokowiMa' ruf cenderung monoton dan ter-branding status quo sehingga banyak wacana retorika dimainkan dari Jokowi-Ma'ruf cenderung reaktif dan responsif. Jokowi juga dinilai cenderung hanyut dengan permainan narasi kubu lawan dengan timbulnya pernyataan genderuwo, sontoloyo.

Hal itu mengakibatkan kampanye belum terfokus. Selain itu, Arie menilai belum ada pembagian peran antara Jokowi dan 
Ma'ruf Amin. Figur Ma'ruf juga dinilai Arie belum bisa menambahkan elektabilitas Jokowi. Pasangan Prabowo-Sandi yang dinilai trennya naik karena mengambil keuntungan dari petahana dengan melakukan serangan-serangan, kemudian diladeni oleh pihak lawan (Putri, 2018). Penelitian ini mengungkapkan upaya berbagai pembentukan citra negatif pasangan calon presiden Jokowi-Ma'ruf Amin. Oleh karena itu, sangat menarik untuk mengungkapkan berbagai citra negatif yang ditujukan kepada pasangan calon presiden Jokowi Ma'ruf.

\section{TEORI}

Teks berbagai pemberitaan merupakan sebuah wacana. Menurut Purbani (2009:1) istilah wacana memiliki pengertian yang beragam tergantung pada konteks apa yang tengah digunakan untuk memperbincangkannya. Secara umum wacana dimengerti sebagai pernyataan-pernyataan. Dalam ranah lingusitik, wacana dipahami sebagai unit kebahasaan yang lebih besar daripada kata atau kalimat, yang dapat melibatkan satu atau lebih orang. Jadi, sebuah pidato, dialog, polemik, perdebatan, percakapan atau perbincangan dapat dikategorisasikan sebagai sebuah wacana.

Crystal dan Cook dalam Nunan (Purbani, 2009:2) mendefinisikan wacana sebagai unit bahasa lebih besar daripada kalimat, sering berupa satuan yang runtut/koheren dan memiliki tujuan serta konteks tertentu, seperti ceramah agama, argumen, lelucon, atau cerita. Nunan melihat unsur-unsur keruntutan dan koherensi sebagai hal yang penting untuk menilai sebuah wacana. Lubis (Purbani, 2009:2) mendefinisikan wacana sebagai kumpulan pernyataan-pernyataan yang ditulis, diucapkan, atau dikomunikasikan dengan menggunakan tandatanda.
Istilah wacana yang digunakan dalam Critical Discourse Analysis (CDA) salah satunya dikembangkan ahli linguistik sosial seperti Norman Fairclough. Analisis wacana kritis Model Fairclough menempatkan wacana atau penggunaan bahasa sebagai praktik sosial; wacana atau penggunaan bahasa dihasilkan dalam sebuah peristiwa diskursif tertentu; wacana yang dihasilkan berbentuk sebuah genre tertentu (Ahmadi F., 2014:255). Apabila dikaitkan dengan penelitian ini, analisis wacana kritis Model Fairchlough menempatkan wacana atau penggunaan bahasa tentang pembentukan citra negatif terhadap calon presiden Jokowi Ma'ruf sebagai praktik sosial. Penafsiran wacana ini tidak bisa dilepaskan dari konteks sosial budaya masyarakat Indonesia.

Analisis wacana kritis model Fairclough dikenal dengan sebutan analisis tiga dimensi. Analisis tiga dimensi ini ialah 1) analisis tekstual (level mikro) adalah analisis deskriptif terhadap dimensi teks; 2) analisis praktik wacana (level meso) adalah analisis interpretatif terhadap pemproduksian, penyebaran, dan pengonsumsian wacana, termasuk intertekstualitas dan interdiskursivitas; 3) analisis sosiokultural (level makro) adalah analisis eksplanatif terhadap konteks sosiokultural yang melatarbelakangi kemunculan sebuah wacana (Fairclough dalam Ahmadi F., 2014:255).

Penerapan analisis wacana kritis sudah banyak dilakukan. Beberapa penelitian yang relevan dengan penelitian tersebut sebagai berikut. Pertama, penelitian Analisis Wacana Pembentukan Stereotip Pemerintah oleh HTI (Kusno dkk., 2017). Dalam penelitian tersebut, hasil analisis wacana kritis terhadap teks berita dalam tabloid Al Islam yang dimuat dalam laman terdapat temuan terkait upaya pembentukan stereotip negatif tentang pemerintah seperti ketidakmampuan pemerintah, sistem ekonomi liberal, 
keberpihakan pemerintah pada kapitalis, politik transaksional, dan keberpihakan pemerintah pada asing. Berbagai serangan terhadap kondisi dan kebijakan pemerintah dilakukan berulang-ulang sehingga membentuk stereotip negatif tentang pemerintah. Berbagai kondisi tersebut yang mendasari HTI menawarkan solusi perlu penerapan Syariat Islam dan perlunya pemimpin muslim yang bertaqwa. Solusi yang disajikan HTI membangun stigma positif terhadap garis perjuangan HTI.

Kedua, penelitian Analisis Wacana Percakapan Warga dalam Grup Facebook Bubuhan Samarinda: Identifikasi Potensi Konflik Sosial (Kusno, 2017). Hasil penelitian menunjukkan bahwa adanya potensi konflik bernuansa SARA yang didominasi faktor kesukuan. Hal itu didukung oleh tingginya primordialisme warga. Munculnya propaganda bahwa suku tertentu harus disegani. Adanya provokasi antara suku asli dengan pendatang yang lebih banyak dipicu kecemburuan sosial. Terbentuknya stigma bahwa pendatang menjadi biang masalah di Kota Samarinda karena hanya mengeksploitasi kekayaan Kalimantan. Potensi kekerasan menguat karena keberadaan organisasi massa yang mendasarkan pada kesukuan.

Berdasarkan hasil dua penelitian tersebut menunjukkan bahwa analisis wacana kritis Model Fairclough mampu mengungkapkan pemaknaan wacana yang berbeda. Analisis wacana kritis Model Fairclough mampu menempatkan wacana atau penggunaan bahasa sebagai praktik sosial dan terbukti mampu mengungkapkan pemaknaan secara lebih menyeluruh dari berbagai sudut pandang.

\section{METODE}

Dalam penelitian ini menggunakan metode penelitian kualitatif yang bersifat deskriptif. Metode penelitian kualitatif me- rupakan prosedur penelitian yang menghasilkan data deskriptif berupa kata-kata tertulis dan lisan tentang sifat individu, keadaan, gejala dari kelompok tertentu yang dapat diamati (Moleong, 1994:6).

Objek penelitian ini adalah berbagai pemberitaan dan pernyataan beberapa tokoh tentang upaya pembentukan citra negatif capres Jokowi-Ma'ruf. Data dan sumber data yang digunakan dalam penelitian ini berupa dokumen. Sumber data dokumen yaitu berbagai pemberitaan di media massa. Sedangkan teknik analisa data menggunakan model interaktif, seperti yang dikemukakan Miles \& Huberman (2007:19-20), yang terdiri dare tiga komponen analisis, yaitu reduksi data, sajian data, dan penarikan simpulan atau verifikasi. Aktivitas ketiga komponen itu dilakukan dalam bentuk interaktif dengan proses pengumpulan data.

\section{PEMBAHASAN}

Pasangan calon presiden petahana Jokowi dan Ma'ruf Amin diprediksi menjadi pemenang Pilpres 2019 mengalahkan pasangan Prabowo dan Sandiaga Uno. Berbagai upaya dilakukan untuk mengalahkan pasangan Jokowi-Ma'ruf. Berbagai isu negatif dihembuskan untuk menurunkan elektabilitas Jokowi-Ma'ruf. Berikut ini analisis wacana kritis tentang deretan isu negatif yang ditujukan kepada pasangan Jokowi-Ma' ruf Amin.

Berdasarkan analisis tekstual (analisis mikro) berikut ini beragam isu negatif seperti yang dimuat dalam berbagai media.

\section{Jokowi Anti-Islam dan Ulama}

Sejak kasus penistaan agama yang melibatkan Ahok, Jokowi dipersepsikan antiIslam dan ulama. Persepsi tersebut dibentuk karena ada kesan bahwa Presiden Jokowi melindungi Ahok. Sejak itu, semakin diben- 
tuk persepsi bahwa Jokowi anti-Islam dan ulama.

(1) "Banyak sekali isu ke saya. Kriminalisasi ulama, anti-Islam. Loh, loh. Saya tiap hari, tiap minggu masuk pondok pesantren dengan ulama. Hari santri yang buat Perpres saya. Kok dibilang antiulama, anti-Islam?" ujarnya saat membagikan sertifikat tanah bagi warga Pondok Cabe, Tangerang Selatan, Jumat (25/1/2019).

Menurutnya, narasi-narasi negatif tersebut sebetulnya tidak masuk akal karena fakta berbicara sebaliknya. Kendati demikian, katanya, masih saja ada sebagian masyarakat yang memercayai isu tersebut.

Presiden Jokowi menegaskan bahwa dirinya tidak anti-Islam. Ia menyebutkan kalau tudingan dirinya anti-Islam justru bertolak belakang dengan posisinya yang dekat dengan ulama dan tokoh-tokoh besar agama Islam.

"Bolak-balik kayak gitu kalau gampang percaya, termakan, bahaya sekali. Ini hanya tujuan politik, bukan yang lain-lain. Jangan ajarkan masyarakat hal yang tidak logis," ulasnya (Fadillah, 2019).

Jokowi dituduh melakukan kriminalisasi terhadap ulama dan anti-Islam. Menurut penuturan Jokowi, dirinya tiap minggu masuk pondok pesantren dengan ulama. Jokowi pun membuat Perpres tentang Hari Santri. Jokowi beranggapan narasi-narasi negatif tersebut sebetulnya tidak masuk akal karena fakta berbicara sebaliknya. Sayangnya, masih saja ada sebagian masyarakat yang memercayai isu tersebut. Jokowi menegaskan bahwa dirinya tidak anti-Islam. Tudingan Jokowi anti-Islam justru bertolak belakang dengan posisinya yang dekat dengan ulama dan tokoh-tokoh besar agama Islam. Sebaliknya, kubu Prabowo juga diuntungkan dengan adanya politik identitas seperti penyematan gelar ulama pada Sandiaga Uno.

Prabowo-Sandi juga diuntungkan dengan pembelahan suara masyarakat dalam konteks sentimen agama. Jadi, berhasil simbolik politik identitas dan tugas utamanya bisa mengambil keuntungan elektoral ketika ada pembelahan sentimen agama, itu menguntungkan elektoralnya kubu PrabowoSandi (Putri, 2018).

\section{Jokowi Seorang PKI}

Isu yang menyerang Jokowi pada Pilpres 2014 dan 2019 salah satunya dituduh sebagai seorang PKI. Jokowi dituduh sebagai anak keturunan PKI. Seperti diketahui bersama, PKI merupakan partai yang dilarang setelah serangkaian peristiwa berdarah G 30 S PKI. Masyarakat Indonesia sudah pasti trauma dengan peristiwa tersebut. Pembentukan opini bahwa Jokowi sebagai keturunan PKI tentu memunculkan kekhawatiran akan tumbuhnya lagi PKI di Indonesia. Berikut ini pemberitaan seputar mempersepsikan Jokowi sebagai seorang PKI.

(2) Isu ini telah berkembang sejak pemilu 2014. Berkali-kali Jokowi menunjukkan kekesalan akan isu ini dan berkali-kali pula Jokowi meminta agar tidak ada orang yang menyebarkan kabar bohong tersebut.

Paling parah, Jokowi menceritakan bahwa ada sebuah foto dirinya berada di podium bersama Ketua PKI D. N. Aidit yang sedang berpidato pada 1955. Foto itu menurut Jokowi banyak tersebar di media sosial. "Saya lihat sampai geleng-geleng. Saya lahir saja belum, kok, ada di podium D. N. Aidit. Astaghfirullah. Ampun ya Allah. Sabar. Ini baru satu gambar. Belum gambar lain," kata Jokowi di Samarinda, Kalimantan Timur, Kamis, 25 Oktober 2018(Nurita, 2018). 
Isu tersebut telah berkembang sejak pemilu 2014. Berkali-kali Jokowi menunjukkan kekesalan akan isu tersebut dan berkalikali pula Jokowi meminta agar tidak ada orang yang menyebarkan kabar bohong tersebut. Jokowi pun menceritakan bahwa ada sebuah foto dirinya berada di podium bersama Ketua PKI D.N. Aidit yang sedang berpidato pada 1955. Foto itu menurut Jokowi banyak tersebar di media sosial. Menurut pengakuan Jokowi, dirinya sampai geleng-geleng heran dengan gambar tersebut.

\section{Infrastruktur Hanya untuk Orang Kaya}

Pada awal pemerintahan Presiden Jokowi lebih menekankan pada sektor infrastruktur. Keunggulan Jokowi dalam infrastruktur berusaha dibalik dengan membuat narasi bahwa infrastruktur hanya untuk kalangan berada. Masyarakat kecil tidak ikut merasakan manfaat pembangunan berbagai infrastruktur. Berikut ini pemberitaan yang mengungkapkan tanggapa negatif terhadap program insfrastruktur yang digalakkan Jokowi. Berikut pemberitaan terkait pembentukan persepsi bahwa pembangunan infrastruktur hanya untuk kepentingan orang kaya.

(3) Bekas Menteri Koordinator Bidang Kemaritiman Rizal Ramli mengkritik dalam_4,5 tahun pemerintahan Presiden Joko Widodo atau Jokowi yang selalu membanggakan proyek infrastruktur.

Meski pembangunan infrastruktur di era Presiden Jokowi memang all out, tapi Rizal Ramli menyebut hal tersebut malah berdampak negatif. "Satu proyek dia kunjungi delapan kali sudah kayak mandor saja. Memang banyak kemajuan secara fisik, tapi meninggalkan trauma tiga ' $O$ ', "kata Rizal Ramli dalam diskusi bareng Aliansi
Pengusaha Nasional DKI di Hotel Century, Jakarta, Senin, 8 April 2019.

O pertama, menurut Rizal Ramli, adalah Over Supply karena pembangunan dengan dana yang jor-joran. Sedangkan O kedua adalah Over Price karena yang melaksanakan pembangunan infrastruktur adalah Badan Usaha Milik Negara atau BUMN. "BUMN sudah biasa markup 30 sampai 50 persen," ucapnya.

Sementara O ketiga adalah Over Borrowing. "Ketiga karena pada dasarnya BUMN gak punya uang akhirnya terjadi over borrowing. Jadi mau tak mau disubsidi dari APBN dan BUMN harus meminjam," ujarnya sehingga, kata Rizal Ramli, peningkatan pinjaman perusahaan BUMN dalam 4,5 tahun terakhir naik. Di masa mendatang, menurut dia, seharusnya tidak ada lagi proyek berbayar dibiayai dari Anggaran Pendapatan dan Belanja Negara atau APBN.

Menteri Koordinator Bidang Kemaritiman Rizal Ramli mengkritik dalam 4,5 tahun pemerintahan Presiden Joko Widodo atau Jokowi yang membanggakan proyek infrastruktur. Meski pembangunan infrastruktur di era Presiden Jokowi memang besar-besaran, tetapi Rizal Ramli menyebut hal tersebut malah berdampak negatif. Pembangunan infrastruktur membuat suplai berlebih dengan dana jor-joran, dianggap adanya penggelembungan nilai proyek dan peminjaman berlebih.

Lebih lanjut, serangan terhadap Jokowi terkait infrastruktur adalah sebagai berikut.

(4) Menurut Rizal Ramli, duit APBN hanya boleh digunakan jalan negara atau jalan provinsi yang gratis. "Misalnya jalan tol itu berbayar, harusnya diserahkan ke swasta dan swasta yang penting rate of return di dalam 
dolar itu 11 persenan. Yang kedua dibantu pembebasan tanah," ujar dia. Ia juga mengkritik pembangunan jalan tol selama ini diperuntukkan bagi orang kaya, kecuali rakyat pada saat lebaran.

Dalam kesempatan terpisah, calon wakil presiden nomor urut 01 Ma'ruf Amin mengatakan pembangunan infrastruktur penting sebagai modal untuk memajukan perekonomian suatu bangsa. "Infrastruktur memang tidak bisa dimakan. Tapi infrastruktur memudahkan mencari makan, " ujar Ma'ruf Amin saat menyampaikan pidato politik dalam acara Majelis Taklim Bersholawat di Istora Senayan, Jakarta, Senin, 8 April 2019.

Ma'ruf Amin juga menyebutkan infrastruktur memungkinkan aliran barang dan jasa terjadi begitu cepat. "Bagaimana bisa membawa hasil produksi dari satu daerah ke daerah lain tanpa ketersediaan infrastruktur," tuturnya. Selain itu, pembangunan infrastruktur seperti jalan tol telah memudahkan mobilitas masyarakat dari satu daerah ke daerah lain.

Menurut Rizal Ramli, dana APBN hanya boleh digunakan jalan negara atau jalan provinsi yang gratis. Yang kedua dibantu pembebasan tanah. Pembangunan jalan tol selama ini diperuntukkan bagi orang kaya, kecuali rakyat pada saat lebaran. Dalam kesempatan terpisah, calon wakil presiden nomor urut $01 \mathrm{Ma}^{\prime}$ ruf Amin mengatakan pembangunan infrastruktur penting sebagai modal untuk memajukan perekonomian suatu bangsa.

Padahal sisi positif pembangunan infrastruktur adalah memungkinkan aliran barang dan jasa terjadi begitu cepat. Bagaimana bisa membawa hasil produksi dari satu daerah ke daerah lain tanpa ketersediaan infrastruktur. Selain itu, pembangunan infrastruktur seperti jalan tol telah me- mudahkan mobilitas masyarakat dari satu daerah ke daerah lain.

\section{Jokowi Pro Asing dan Aseng}

Jokowi mendapat serangan bahwa pro terhadap asing dan aseng (Cina). Asing dimaknai sebagai negara-negara barat. Aseng dimaknai sebagai negara Tiongkok. Berikut ini beragam pemberitaan terkait Jokowi pro asing dan aseng.

(5) Isu ini juga telah berkembang sejak pemilu 2014 lalu. Tak ayal, isu ini juga membuat Jokowi berang. Menurut Jokowi, isu tersebut tak lain adalah hoax.

"Ada yang mengatakan saya antek aseng, ibu saya Cina. Anak saya bahkan langsung bikin kaos. Mungkin karena dia anak muda, tulisannya: 'Cucunya Oey Hoi Liong', pakai topi juga sama, padahal ibu saya dari Boyolali. Berpolitiklah dengan adab, adat dengan tata krama yang baik," kata Jokowi.(Nurita, 2018).

Isu ini juga telah berkembang sejak pemilu 2014 lalu. Tak ayal, isu ini juga membuat Jokowi berang. Isu tersebut tidak lain adalah hoaks. Ada yang mengatakan Jokowi antek aseng, ibu Jokowi Cina.

\section{Jokowi Raja Hutang}

Serangan lain terhadap Jokowi tentang Jokowi sebagai seorang presiden yang raja hutang. Berikut ini berbagai pemberitaan yang mengungkapkan Jokowi sebagai Presiden yang mengandalkan utang.

(6) Joko Widodo (Jokowi) menanggapi soal isu utang negara selama dia menjabat Presiden RI. Dia menjelaskan, sedari awal dia dilantik, utang negara sudah ribuan triliun. Jokowi mengatakan dirinya sadar 'diserang' oleh berbagai isu. Saat ini, dia 'diserang' isu utang 
negara yang membengkak."Ganti lagi isu utang," kata Jokowi saat menghadiri Konvensi Nasional Galang Kemajuan 2018, yang dihadiri ribuan relawan, di Ballroom Puri Begawan, Bogor, Jawa Barat.

Jokowi menjelaskan, sejak dirinya dilantik, Indonesia sudah memiliki utang sebesar Rp2.700 triliun. Nilai itu kemudian terus membengkak akibat adanya bunga. Jokowi pun meminta masyarakat berpikir jernih terkait isu utang negara selama dia memimpin. Jokowi menegaskan tidak mungkin menambah utang negara dalam jumlah besar (Jornda, 2018).

\section{Jokowi Pro LGBT}

Pada masa kampanye Pilpres 2019, Jokowi banyak diserang dengan isu lesbian, gay, biseksual, dan transgender (LGBT). Jokowi dipersepsikan pro LGBT. Hal itu seperti dalam pemberitaan berikut ini.

(7) Calon presiden petahana Joko Widodo (Jokowi) berbicara tentang fitnah larangan azan dan melegalkan pernikahan sejenis (LGBT) jika dia terpilih kembali sebagai Presiden RI. Dia mengatakan isu fitnah seperti itu sebagai sampah (Jordan, 2019).

Seperti dalam pemberitaan tersebut, calon presiden petahana Joko Widodo (Jokowi) berbicara tentang fitnah larangan azan dan melegalkan pernikahan sejenis (LGBT) jika terpilih kembali sebagai Presiden RI. Jokowi mengatakan isu fitnah seperti itu tidak dapat dipertanggungjawabkan.

\section{Harga Pangan Naik}

Salah satu terpaan serangan negatif pada masa kampanye Pilpres 2019 adalah harga pangan yang naik. Hal itu seperti yang terdapat dalam penggalan artikel berikut ini.

(8) Dalam beberapa hari terakhirini, Jokowi kerap pergi ke pasar tradisional. Musababnya, calon wakil presiden penantang-nya, Sandiaga Uno kerap mengatakan harga bahan pangan naik di pemerintahan Jokowi. Sandiaga menyindir kondisi ekonomi menggunakan tempe, yang kini menurutnya sudah dijual setipis ATM.

Membalas sindiran Sandiaga, Jokowi berkunjung ke beberapa pasar. Jokowi mengklaim pemerintah berhasil menjaga stabilitas harga bahan pokok di pasar. Hal ini, kata dia, sejalan dengan tingkat inflasi yang berkisar 3,5 persen.

Jokowi kerap pergi ke pasar tradisional. Hal itu disebabkan Sandiaga Uno kerap mengatakan harga bahan pangan naik pada masa pemerintahan Jokowi. Sandiaga menyindir kondisi ekonomi menggunakan tempe, yang kini menurutnya sudah dijual setipis ATM. Membalas sindiran Sandiaga, Jokowi berkunjung ke beberapa pasar. Jokowi mengklaim pemerintah berhasil menjaga stabilitas harga bahan pokok di pasar. Hal ini, menurut Jokowi, sejalan dengan tingkat inflasi yang berkisar 3,5 persen.

Berdasarkan analisis teks dilanjutkan pada analisis praktik wacana analisis praktik wacana (level meso). Menurut Fairlough (dalam Jorgensn dan Philips dalam Yusep Ahmadi F. 202014: 261). Analisis praktik kewacanaan ini dipusatkan pada bagaimana teks diproduksi dan dikonsumsi, termasuk di dalamnya menyelisik proses apakah yang dilalui suatu teks sebelum dicetak dan perubahan apa yang dialami sebelum disebarluaskan. 
Berdasarkan analisis data tersebut dapat dipahami adanya beragam persepsi negatif yang disematkan kepada Jokowi. Berbagai serangan negatif tersebut sebagai bentuk perlawanan atas berbagai prediksi yang menyatakan bahwa pasangan calon presiden petahana Jokowi dan Ma'ruf Amin akan menjadi pemenang Pilpres 2019 mengalahkan pasangan Prabowo dan Sandiaga Uno.

Jokowi diframing untuk membentuk persepsi negatif. Menurut Edelmen (Eriyanto, 2015), sebuah realitas bisa jadi dibingkai dan dimaknai secara berbeda oleh media. Kalau saja ada realitas dalam arti yang objektif, bisa jadi apa yang ditampilkan dan dibingkai oleh media berbeda dengan realitas objek tersebut.

Berbagai upaya dilakukan untuk mengalahkan pasangan Jokowi Amin. Berbagai isu negatif disebarkan untuk menurunkan elektabilitas Jokowi Ma'ruf. Sejak kasus penistaan agama yang melibatkan Ahok, Jokowi dipersepsikan anti-Islam dan ulama. Persepsi tersebut dibentuk karena ada kesan bahwa Presiden Jokowi melindungi Ahok. Sejak itu, semakin dipersepsikan bahwa Jokowi anti-Islam dan ulama.

Sebaliknya, kubu Prabowo juga diuntungkan dengan adanya politik identitas seperti penyematan gelar ulama pada Sandiaga Uno. Sebaliknya, Prabowo-Sandi juga diuntungkan dengan pembelahan suara masyarakat dalam konteks sentimen agama. Politik simbolik identitas dinilai berhasil karena bisa mengambil keuntungan elektoral ketika ada pembelahan sentimen agama.

Isu yang menyerang Jokowi pada Pilpres 2014 dan 2019 salah satunya diserang sebagai seorang PKI. Jokowi dituduh sebagai anak keturunan PKI. Seperti diketahui bersama, PKI merupakan partai yang dilarang setelah serangkaian peristiwa ber- darah G 30 S PKI. Masyarakat Indonesia sudah pasti trauma dengan peristiwa tersebut. Pembentukan opini bahwa Jokowi sebagai keturunan PKI tentu memunculkan kekhawatiran akan tumbuh lagi PKI di Indonesia.

Isu negatif lainnya, tentang pembangunan infrastruktur. Sejak awal pemerintahan periode 2014-2019, Presiden Jokowi lebih menekankan pada sektor infrastruktur. Keunggulan Jokowi dalam infrastruktur berusaha dibalik dengan membuat narasi bahwa infrastruktur hanya untuk kalangan berada. Sedangkan, masyarakat kecil tidak ikut merasakan.

Perlu disadari bersama bahwa pembangunan infrastruktur penting sebagai modal untuk memajukan perekonomian suatu bangsa. Infrastruktur memungkinkan aliran barang dan jasa terjadi begitu cepat. Selain itu, pembangunan infrastruktur seperti jalan tol telah memudahkan mobilitas masyarakat dari satu daerah ke daerah lain.

Jokowi juga mendapat serangan bahwa pro terhadap asing dan aseng. Asing dimaknai sebagai negara-negara barat. Aseng dimaknai sebagai negara Tiongkok. Isu ini juga telah berkembang sejak pemilu 2014 lalu. Isu tersebut tidak lain adalah hoaks.

Jokowi menanggapi soal isu utang negara selama menjabat Presiden RI. Sejak awal dia dilantik, utang negara sudah sebesar Rp2.700 triliun. Nilai itu kemudian terus membengkak akibat adanya bunga.

Pada masa kampanye Pilpres 2019, Jokowi banyak diserang dengan isu LGBT. Dipersepsikan Jokowi pro LGBT. Jokowi mendapat fitnah larangan azan dan melegalkan pernikahan sejenis (LGBT) jika terpilih kembali sebagai Presiden RI.

Salah satu terpaan serangan negatif yang tidak kalah gencar adalah harga pangan yang naik. Jokowi sering pergi ke pasar tradisional untuk membuktikan harga 
barang. Jokowi mengklaim pemerintah berhasil menjaga stabilitas harga bahan pokok di pasar. Hal ini sejalan dengan tingkat inflasi yang berkisar 3,5 persen.

Berdasarkan analisis dimensi praktik sosial budaya (makro). Apabila dicermati, penggunaan berbagai isu negatif tersebut terbukti mampu menggerus peta suara pasangan Jokowi-Ma'ruf. Hanya saja penggunaan berbagai isu negatif untuk menyerang pihak lain sangat berbahaya dan terbukti memecah belah masyarakat.

Setidaknya sejak munculnya kasus dugaan penistaan agama yang dilakukan Ahok pada Pilgub DKI Jakarta 2017 terdapat indikasi munculnya keterbelahan sosial. Meskipun persoalan hukumnya telah selesai, dampak sosialnya masih terus terasakan. Bahkan, terasa menguat jelang dan saat Pilpres 2019. Hal tersebut khususnya tampak dari saratnya slogan, diksi, dan ujaran negatif, tidak etis, serta sarkastik yang memenuhi media sosial (medsos). Elemen-elemen bangsa seolah tak berdaya.

Menurut Zuhro (2019) selama ini Indonesia dikenal sebagai bangsa yang moderat dan sangat toleran. Hubungan antarsuku bangsa, ras, dan agama relatif baik. Hal tersebut terbukti dari adanya semboyan Bhinneka Tunggal Ika yang menjadi prinsip hidup berbangsa dan bernegara. Dalam perkembangannya, menjelang dan saat pilpres kali ini ciri khas masyarakat Indonesia yang dikenal sopan, santun, ramah, dan penuh keadaban seperti mengalami perubahan. Sebagian masyarakat terjebak ke dalam perilaku kekerasan dan bentuk-bentuk ketidakadaban lainnya. Sulit dinafikan bahwa nuansa panasnya politik dalam Pilpres 2019 berbeda dengan pilpres sebelumnya. Faktor utamanya kiranya bukan karena Pilpres 2019 langsung bersifat head to head, karena hal tersebut juga terjadi pada 2014.

Apa yang diungkapkan Siti Zuhro memang benar adanya. Pada Pilpres 2019, pen- dekatan tidak pada keunggulan program kerja yang ditawarkan, tidak saling serang antarkandidat. Oleh karena itu, dalam kesempatan Pilpres maupun Pilkada, harus diisi dengan adu program, bukan saling menjelekkan antarkandidat. Pemilu sebaiknya diisi dengan perang gagasan agar masyarakat dapat menilai kelebihan masing-masing kandidat, bukan beradu saling mencari kekurangan.

Selain itu, proses pendalaman demokrasi/konslidasi demokrasi memerlukan peran penting semua pemangku kepentingan terkait pemilu dan juga elemen-elemen kekuatan lainnya seperti masyarakat, elite/ aktor, media massa, dan media sosial serta lembaga survei. Independensi, kedewasaan dan partisipasi kekuatan-kekuatan sosial (societal forces) tersebut sangat diperlukan. Masyarakat perlu tetap kritis dalam mengawal pemilu dan hasilnya. Media massa bisa menjadi pemasok berita yang objektif dan melakukan kontrol sosial yang berpihak pada rakyat (Zuhro, 2019). Apabila itu dilakukan akan mampu melahirkan pemilu yang demokratis dan menjauhkan dari perpecahan.

\section{SIMPULAN}

Beragam persepsi negatif yang disematkan kepada Jokowi. Berbagai serangan negatif tersebut sebagai bentuk perlawanan atas berbagai prediksi yang menyatakan bahwa pasangan calon presiden petahana Jokowi dan Ma'ruf Amin akan menjadi pemenang Pilpres 2019 mengalahkan pasangan Prabowo dan Sandiaga Uno.

Berbagai isu negatif disebarkan untuk menurunkan elektabilitas Jokowi Ma'ruf. Isu yang menyerang Jokowi pada Pilpres 2014 dan 2019 salah satunya diserang sebagai seorang PKI. Isu negatif lainnya, tentang pembangunan infrastruktur. Keunggulan Jokowi dalam infrastruktur berusaha dibalik dengan membuat narasi bahwa infrastruktur hanya untuk kalangan berada. 
Sedangkan, masyarakat kecil tidak ikut merasakan.

Jokowi mendapat serangan bahwa pro terhadap asing dan aseng. Jokowi menanggapi soal isu utang negara selama menjabat Presiden RI. Sejak awal Jokowi dilantik, utang negara sudah sebesar Rp2.700 triliun. Nilai itu kemudian terus membengkak akibat adanya bunga.

Pada masa kampanye Pilpres 2019, Jokowi banyak diserang dengan isu LGBT. Isu lain adalah harga pangan yang naik. Jokowi kerap pergi ke pasar tradisional untuk membuktikan harga barang. Jokowi mengklaim pemerintah berhasil menjaga stabilitas harga bahan pokok di pasar.

Apabila dicermati, penggunaan berbagai isu negatif tersebut terbukti mampu menggerus peta suara pasangan JokowiMa'ruf. Hanya saja penggunaan berbagai isu negatif untuk menyerang pihak lain sangat berbahaya dan terbukti memecah belah masyarakat.

\section{DAFTAR PUSTAKA}

Ahmadi F., Y. D. 2014. Analisis Wacana Kritis: Ideologi Hizbut Tahrir Indonesia Dalam Wacana Kenaikan Harga BBM 2013 di Buletin Al-Islam yang berjudul "Menaikkan Harga BBM: Nenaikkan Kemiskinan." Metalingua: Jurnal Penelitian Bahasa, 12 (2)(Analisis Wacana Kritis), 253-265.

Eriyanto. 2015. Analisis Framing: Konstrukti, Ideologi, dan Politik Media. (N. H. S.A., Ed.). Yogyakarta: LKiS Yogyakarta.

Fadillah, R. 2019. Dituduh Anti Islam, Jokowi: Jangan Ajarkan Masyarakat Hal Tidak Logis. http:// www.rmoljabar.com/read/2019/01/ 25/93190/1/www.rmol.co. Diakses 25 Januari 2019.

Jordan, R. 2019. Geram Difitnah Larang Azan dan Legalkan LGBT, Jokowi: Isu
Sampah! https://news.detik.com/ berita/d-4459262/geram-difitnahlarang-azan-dan-legalkan-lgbt-jokowiisu-sampah. Diakses 2 Juli 2019.

Jornda, R. 2018. Jokowi: Saat Saya Dilantik Utang Negara Rp 2.700 T, Bunganya Rp 250 T. https://news.detik.com/berita/ d-3958869/jokowi-saat-saya-dilantikutang-negara-rp-2700-t-bunganya-rp250-t. Diakses 2 Juni 2019.

Kusno, A. 2017. Analisis Wacana Percakapan Warga dalam Grub Facebook Bubuhan Samarinda: Identifikasi Potensi Konflik Sosial. Masyarakat Dan Budaya, Volume 19, 89-104. http://jmblipi.or.id/index.php/jmb/article/ view/391. Diakses 6 November 2019.

Kusno dkk. 2017. Analisis Wacana Kritis Pembentukan Stereotip Pemerintah oleh HTI. Jurnal Bahasa Dan Sastra, Volume 45,. http://journal2.um.ac.id/ index.php/jbs/article/view/1729/991. Diakses 7 Oktober 2019.

Nurita, D. 2018. Reaksi-reaksi Jokowi Menjawab 3 Isu yang Menyerangnya di Pilpres. https://pilpres.tempo.co/ read/1143432/reaksi-reaksi-jokowimenjawab-3-isu-yang-menyerangnyadi-pilpres. Diakses 1 Juli 2019.

Purbani, W. 2009. Analisis Wacana Kritis dan Analisis Wacana Feminis. http:// staff.uny.ac.id/system/files / pengabdian/dr-widyastuti-purbanima/analisis-wacana-kritis.pdf. Diakses 4 Oktober 2019.

Putri, Z. 2018. Para Syndcate: Elektabilitas Jokowi-Ma'ruf Turun, Prabowo-Sandi Naik. https://news.detik.com/berita/ d-4344183/para-syndcate-elektabilitasjokowi-maruf-turun-prabowo-sandinaik. Diakses 6 November 2019.

Zuhro, S. 2019. Pilpres 2019: Terkoyaknya Kohesi Sosial. https:// news.detik.com/kolom/d-4547358/ 
pilpres-2019-terkoyaknya-kohesisosial. Diakses 3 September 2019.

- - - - - - 2019. Demokrasi dan Pemilu Presiden 2019. Jurnal Penelitian Politik, Volume 16. http:// ejournal.politik.lipi.go.id/index.php/ ipp/article/view/782/541. Diakses 3 September 2019. 